\title{
Accounting
}

\section{The effect of government ownership on Indonesia's state-owned enterprises' (SOE) firm performance}

\author{
Reynaldi Hermansjah ${ }^{a^{*}}$, Sugiarto ${ }^{\mathrm{b}}$, Gracia Shinta S. Ugut ${ }^{\mathrm{a}}$ and Edison Hulu ${ }^{\mathrm{c}}$
}

${ }^{a}$ Doctoral Program, Universitas Pelita Harapan, Indonesia

${ }^{b}$ Faculty Member of Universitas Prasetiya Mulya, Indonesia

${ }^{c}$ Lecturer, Universitas Pelita Harapan, Indonesia

\section{H R O N I C L E}

Article history:

Received: November 30, 2020

Received in revised format: April 32021

Accepted: April 4, 2021

Available online:

April 4, 2021

Keywords:

Government ownership

SOE

Privatization

Firm performance

$R O A$

$R O E$

\section{A B S T R A C T}

This study aimed to analyze the impact of government ownership on Indonesia's SOE's financial performance, measured by Return on Assets (ROA) and Return on Equity (ROE) of 20 SOEs that are listed on the Indonesia Stock Exchange during the period 2013 - 2019, using the panel data models. According to the results, government ownership has a positively significant impact on the firm performance (ROA and ROE). Furthermore, the results show that along with government shares, debt to equity ratio, dividend payout ratio, and log of total assets also have significant relationships to the firm performance.

\section{Introduction}

Studies on the state or government ownership and its impact on firm performance remains to draw wide attention among academics, investors, and policy makers. Government ownership impact on state-owned enterprises has become a compelling ownership structure to be studied, given that the government has the authority and substantial influence in the policy making process. On one hand, government ownership is believed to bring a 'helping hand' which assumes that the higher proportion of government ownership in a firm, the more capital subsidy is provided by the government. On the other hand, government ownership is supposed to bring a 'grabbing hand' which assumes that the government will extract more of the firm's profit as a result of its ownership to the benefit of politicians and bureaucrats (Tian \& Estrin, 2008).

The role of government ownership in an enterprise may result in the existence of better policies that can improve the management behavior (Razak et al., 2008). Furthermore, the government's ability to reduce the agency conflicts can have a positive effect on the firm's financial performance (Razak et al., 2008; Najid \& Rahman, 2001; Sun \& Tong, 2002). However, on the other side, some studies show there is a negative relationship between government ownership and financial firm performance (Ting \& Lean, 2015; Tran et al., 2014).

* Corresponding author.

E-mail address: rh9342@student.uph.edu (R. Hermansjah) 
This study focuses on analyzing the impact of government ownership on firm performance of Indonesia's State-owned Enterprise (SOE) that are listed in the Indonesia Stock Exchange (IDX). Twenty SOEs data are used in the population within the period of 2013 to 2019 . The analysis method used in this study is panel data regression. In addition to government ownership, some variables that represent the firm characteristics are used as predictor variables: management shares, debt to equity ratio, dividend payout ratio, and log of total assets.

The remainder of this paper is organized as follows. Section 2 introduces the literature in this area of study. Sections 3 describes the material and methodology of this study. In Section 4, panel data regressions are used to examine the relationship and the regression results are reported. Finally, conclusions and policy implications are presented in Section 5.

\section{Literature review}

State-Owned Enterprises, or Government-Owned Enterprises, are business enterprises that are owned by the government. StateOwned Enterprises have the following particular characteristics: they are owned by the government, engaged in the production of goods and services for sale, and their sales revenues should bear some relationship to cost (MacAvoy et al., 1989). In a normative sense, State-Owned Enterprises in Indonesia are regulated by at least two regulations, namely Law Number 19 of 2003 on the State-Owned Enterprises ("SOEs Law") and, Law Number 23 of 2014 on Local Government ("Local Government Law"). Referring to the SOEs law, SOEs are defined as "business entities wholly or largely owned by the state through direct participation derived from separated state assets.", whereas LGEs defined SOEs as "business entities in which the local government own the capital wholly or partially." Both definitions underline the importance of government ownership of the SOEs and SOEs as public bodies. According to Indonesia's SOE Law Number 19 from 2003, a state-owned enterprise is defined as a business entity of which all or at least $51 \%$ shares is owned by the Republic of Indonesia through direct investment, with the main objective of it is pursuing profit. By government being a major owner of SOEs, government ownership becomes one of the interesting ownership structures to be examined. Government has the authority and great influence in making policy on various lines, even in the economic field, the role of government ownership in an enterprise can implement policies that can discipline self-interest management behavior (Razak et al., 2008). It is necessary to clarify and communicate clearly the relationship between the government and the SOEs, especially regarding government objectives, monitoring, and reporting as well as the measurement of the positions and performance of SOEs' directors, in order to be able to maintain the ability of SOEs to fulfill their objectives in pursuing profit for the economic. The clear relationship between the government and the SOEs, as the OECD (1998) discussed, includes strengthening financial discipline, concentrating on the core business, and controlling the relationships between the government and the SOEs. The subject of government ownership has inspired many previous studies in Asia. However, the empirical results for the relationship between government ownership and firm performance has been mixed. Qi et al. (2000) examine a sample of Shanghai Stock Exchange-listed Chinese firms from 1991 to 1996 and conclude that state equity ownership is negatively related to operating performance. Further, Sun et al. (2002) examine a sample of Chinese listed firms from 1994 to 1997 and conclude that state equity ownership has an inverted U-shaped or concave relationship with market performance. They reason that government political support and business connections provided through state ownership are valuable and necessary to vitalize performance.

In Malaysia, the government's ownership and their ability to reduce the agency conflicts in SOEs has been proved to have a positive effect on the financial performance (Razak et al., 2008). Studies by Eforis (2018) shows that there is a positive impact of Indonesia's state ownership on the firm's financial performance, measured by return on assets (ROA). On the contrary, other studies point out that there is a negative relationship between government ownership and financial performance (Ting \& Lean, 2015; Tran et al., 2014). Ng et al. (2009) and Hess et al. (2010), who examine Chinese listed firms from 1996 to 2003 and 2000 to 2004, respectively, both find a convex relationship between government ownership and market performance. In conclusion, the relationship between government ownership and firm performance is still unresolved. However, the mixed empirical results in previous studies may be related to different model specifications, firm performance measurements, and sample selection techniques ( $\mathrm{Yu}$ et al., 2013). Most studies have used OLS regressions to cross-sectional data or balanced panel data and the financial ratios used to measure firm performance varied from return on assets (ROA), return on equity (ROE), Tobin's Q, and the market to book ratio (MBR).

Indonesia's government expects SOEs to drive economic growth, but by contrast the government must subsidize any SOE which experiences a loss. This shows the dependency of Indonesia's SOEs to the government. Further, government subsidy also makes it more difficult for SOEs to be efficient. The role of government in SOEs becomes unclear because the result of subsidy policy makes it difficult to compare SOEs with private companies (Soejono, 2018). One way to solve this is by privatization. Previous studies have shown that the financial performance of government companies increases after privatization (Dharwadkar et al., 2000; Gupta, 2005; Urga et al., 2007; Ochieng \& Anwar, 2014). Buchner et al. (2016) on the other sides states that there is no single model for successful privatization. It can be anything from government support, sales to the private sector to transfer of ownership to employees. 
D'souza et al. (2000) shows that the only variable that has a positive impact to the firm performance post-privatization is management ownership or insider ownership; one percent increase in employee ownership will result in a 7.49 percent increase in real capital spending post privatization. Based on research by Itturalde et al. (2011), it is proved that there is an influence of insider ownership on company performance. Ahmed and Hadi (2017) who examined companies in the MENA region (Jordan, Bahrain, Oman, Qatar, Tunisia, UAE, Morocco, Kuwait and Egypt) found a positive relationship between management share ownership and company performance in the MENA region, using ROA and ROE to represent firm performance. Furthermore, according to Kristiani (2014), insider ownership or share ownership by management, such as the board of commissioners and directors, motivate management to participate in improving the company's stock performance.

Giovanis and Ozdamar (2014) show that company size and debt ratio have a positive influence on profitability at a certain point, but may also decrease the profitability. On the other side, the debt ratio has a negative effect on company performance, and this is consistent in several studies (Hossain et al., 2001; Jackling and Johl, 2009; Li and Wong, 2003; Panasian et al., 2008).

The key purpose of this study is to examine the impact of government ownership on Indonesia's SOEs firm performance. This study contributes by providing the most recent analysis of the impact of government ownership on firm performance of twenty Indonesia's State-owned Enterprise (SOE) that are listed in the Indonesia Stock Exchange (IDX) in the period of $2013-2019$.

Based on the above arguments, the following hypotheses are posited:

$\mathrm{H}_{1}$ : Government ownership has a positive impact on firm performance.

$\mathrm{H}_{2}$ : Management ownership has a positive impact on firm performance.

$\mathrm{H}_{3}$ : Debt to equity ratio has a positive impact on firm performance.

$\mathrm{H}_{4}$ : Dividend payout ratio has a positive impact on firm performance.

$\mathrm{H}_{5}$ : Log of total assets has a positive impact on firm performance.

\section{Research model}

\subsection{Data and variable definition}

The data set is taken from Indonesia Stock Exchange (IDX) database and covers 20 Indonesia's listed SOEs, including bank and non-bank SOEs from 2013 to 2019, resulting in 140 panel observations. The term financial performance refers to a firm's ability to generate new resources from day-to-day operations over a given timeframe, and it is measured by its net income and cash from operations (Yu, 2013). This study uses return on assets (ROA) and return on equity (ROE) to measure firm's profitability. ROA is calculated by dividing total profits plus financial expenses by average total assets. Average total assets are the average of beginning total assets plus ending total assets. ROE is obtained by dividing net profits by average shareholders' equity. Average shareholders' equity is the average of ending shareholders' equity from last year plus ending shareholders' equity in the present year. As for the predictor variables, in addition to the government ownership, several firm characteristics: management ownership, debt to equity ratio, dividend payout ratio, and the log of total assets are used. The measurements of the research variables used in this study are shown in Table 1. From the sample, there is no single missing data, from each firm in the period of $2013-2019$, thus balanced panel data are used.

Table 1

Research variables.

\begin{tabular}{ll}
\hline Variable & Measurement \\
\hline Return on assets (ROA) & (total profits + financial expenses)/average total assets \\
Return on equity (ROE) & net profits/average shareholders' equity \\
Management Ownership (IS) & total number of shares owned by managements/the total shares outstanding \\
Government Ownership (RI) & total number of shares owned by Republic Indonesia/total shares outstanding \\
Debt to equity Ratio (DE) & total liabilities/shareholder equity \\
Log of total assets (LOGTA) & log of company total assets \\
Dividend payout ratio (DPR) & total dividends/net income \\
\hline
\end{tabular}

\subsection{Empirical model}

This study uses panel data regression analysis to test the relationship between government ownership and firm (SOE) performance. The panel data take in repeated measures of more than one variable on more than one firm. The panel data analysis techniques are used since they work better in studying the dynamics of change (Gujarati, 2013). Three different models (common effects model (CEM), fixed effects model (FEM), and random effects model (REM)) may be used in the panel data analysis 
depending on the nature of the data. We use a Hausman test in this study to know whether the fixed effects is better than the random effects model.

The regression equation used in this study is shown in Eq. (1).

$$
\operatorname{Perf}_{i t}=\beta_{0}+\beta_{1} D E_{i t}+\beta_{2} D P R_{i t}+\beta_{3} L O G T A_{i t}+\beta_{4} I S_{i t}+\beta_{5} R I_{i t}+\alpha_{i}+\gamma_{t}+\varepsilon_{i t}
$$

In Eq. (1), $P e r f_{i t}$ represents dependent variables to measure firm performance for firm $i$ at time $t$, including return on assets (ROA) and return on equity (ROE). This study uses the five predictor variables that are commonly used in the previous literature. Each vector of variables shown in Eq. (1) represents firm characteristics such as debt to equity ratio (DE), dividend payout ratio (DPR), LOGTA (log of total assets), management ownership (IS), and government ownership (RI). $\beta$ represents the coefficients to be estimated, $\varepsilon_{i t}$ is the error term, $\alpha_{i}$ is the firm fixed effect, and $\gamma_{t}$ is the year fixed effect.

\section{Results and discussion}

\subsection{Regression analysis}

Table 2 presents the descriptive statistics of the secondary data collected of each variable. It summarizes the mean, minimum, maximum, median, and standard deviation from the regression's observation. Average government ownership is $65.3 \%$, average $\mathrm{ROA}$ is $3.9 \%$ and average $\mathrm{ROE}$ is $10.6 \%$. average debt to equity ratio, dividend payout ratio, log of total assets, and management ownership are $83.7 \%, 27.4 \%, 10.7$, and $0.001 \%$ respectively.

\section{Table 2}

Summary statistics

\begin{tabular}{|c|c|c|c|c|c|}
\hline Variable & Mean & Median & Max & Min & Std. Dev. \\
\hline Debt to equity Ratio (DE) & 0.837 & 0.620 & 0.578 & 0.000 & 0.727 \\
\hline Dividend payout ratio (DPR) & 0.274 & 0.250 & 0.900 & 0.000 & 0.197 \\
\hline Log of total assets (LOGTA) & 10.717 & 10.602 & 14.164 & 7.131 & 1.742 \\
\hline Management ownership (IS) & 0.000 & 0.000 & 0.002 & 0.000 & 0.000 \\
\hline Government ownership (RI) & 0.653 & 0.650 & 0.940 & 0.510 & 0.114 \\
\hline ROE & 0.106 & 0.140 & 0.370 & -0.560 & 0.137 \\
\hline $\mathrm{ROA}$ & 0.039 & 0.030 & 0.220 & -0.150 & 0.068 \\
\hline
\end{tabular}

Table 3

Correlation matrix

\begin{tabular}{lllllll}
\hline & DE & DPR & LOGTA & IS & RI & \\
\hline DE & 1.000 & & & & & \\
DPR & -0.431 & 1.000 & 0.354 & 1.000 & & \\
LOGTA & 0.129 & 0.120 & 0.746 & 1.000 & \\
IS & -0.004 & -0.498 & -0.549 & -0.264 & 1.000 \\
RI & 0.176 & 0.634 & -0.086 & -0.151 & -0.225 \\
ROA & -0.580 & 0.575 & 0.242 & 0.217 & -0.420 \\
ROE & -0.521 & & 0.790 & 1.000 \\
\hline
\end{tabular}

\section{Table 4}

Panel data regressions

\begin{tabular}{lll}
\hline Dependent Variables & ROA & ROE \\
\hline Independent variables & FE coef. & FE coef. \\
\hline & Model 1 & Model 2 \\
Debt to equity ratio & $-0.024^{* * *}$ & $-0.087 * *$ \\
Dividend payout ratio & $0.057^{* *}$ & 0.040 \\
Log of total assets & $-0.015^{* *}$ & -0.018 \\
Management ownership & 0.004 & 0.006 \\
Government ownership & $0.171 * *$ & $0.651 * * *$ \\
Constant & 0.062 & -0.115 \\
$F$-statistic & 0.000 & 0.000 \\
$R^{2}$ & $77.8 \%$ & $79.2 \%$ \\
Adjusted $R^{2}$ & $73.3 \%$ & $14.8 \%$ \\
$N$ & 140 & 140 \\
\hline
\end{tabular}

Notes:

*significant at the $10 \%$ level, ** significant at the 5\% level, *** significant at the $1 \%$ level. 
Table 3 shows that the correlations of each pairwise variable are lower than $80 \%$. There are two models using fixed effect results reported in Table 4. In Model 1, the dependent variable used is return on assets. Model 1 reveals that debt equity ratio and log of total assets have a significant negative impact to ROA, while dividend payout ratio and government ownership have a significant positive impact to ROA. In model 2, the dependent variable used is return on equity. Model 2 reveals that debt to equity ratio and government ownership have a significant positive impact to ROE. The statistical value $F$ is meaningful since it is lower than the significance level of 0.05 , which resulted in rejecting the null hypothesis, meaning that there are relationships between the predictor and predicted variables. The $\mathrm{R}^{2}$ score shown in Table 4 describes how independent variables in Model 1 and Model 2 explain about $77.8 \%$ and $79.2 \%$ of the variations in the data respectively, showing that the firm characteristics used in the models explain about $77.8 \%$ and $79.2 \%$ of the SOEs performance. The non-measurable portion of the regression model here is about $22.2 \%$ and $20.8 \%$ due to the impact of other important factors on the performance of the firms, that are not included in the analysis.

In this study, it is proved from the Hausman test results that the fixed effect model is better and so the reported results in Table 4 are using fixed effects model (FEM) for the data panel analysis. Both models implies that government-owned share proportion however will have a good impact on firm performance. This is consistent with the previous study by Jiang et al. (2008) that used 821 listed companies on the Shanghai Stock Exchange and ROA and ROE as firm performance measurement. There are possible grounds for this. One of the main explanations is the campaign of "BUMN Bersinergi" (synergy between state owned enterprises). "BUMN Bersinergi" is a commitment between Indonesia's SOEs (BUMN) with the aim of optimizing the resources and skills of each SOE within the framework of synergy among SOEs (Eforis, 2018). This campaign describes the importance of SOEs to the Indonesian government, through the synergy created by several SOEs, in optimizing their resources, opportunities to create better firm performance and profitability.

The types of government support for SOEs also include funds to purchase new shares that will increase the government's shares, funds for SOEs that will not affect the government stocks due to public service obligations, or a combination of policies affecting SOEs' liabilities and equity increases.

In spite of the positive relationship between government ownership and SOE's firm performance, Government still needs to formulate the right mix of policies in support for advancing the SOE's more sustainable financial performance in the future.

\section{Conclusion}

This study has investigated the impact of government ownership on the performance of Indonesia's SOEs which is measured by return on assets (ROA) and return on equity (ROE). The findings complement the previous works on Indonesia SOE's empirical studies (Eforis, 2018) and show that government ownership has a positive significant effect on both ROA and ROE. Other firm characteristics impact on the firm performance are also measured. Dividend payout ratio has a positive significant effect on ROA, while log of total assets has a negative impact on ROA. Debt to equity ratio has a negative significant effect on both ROA and ROE.

This study provides evidence and reveals that government-owned share proportion will have a good impact on firm performance, indicating that firms with higher government ownership will achieve higher firm performance due to government support. Based on the findings, the government, being the largest shareholder, can provide a more accurate intervention and solutions to the financial performance of the SOEs in the form of government support policy for financing and other non-financial resources to the SOEs.

\section{References}

Ahmed, N., \& Hadi, O.A. (2017). Impact of ownership structure on firm performance in the MENA region: an empirical study. Accounting and Finance Research, 6(3), 105-115.

D'Souza, J., Nash, R. C., \& Megginson, W. L. (2000). Determinants of performance improvements in privatized firms: The role of restructuring and corporate governance. Available at SSRN 243186.

Dharwadkar, B., George, G., \& Brandes, P. (2000). Privatization in Emerging Economies: an Agency Theory Perspective. Academy of Management Review, 25(3), 650-669.

Eforis, C (2018). State ownership and Corporate Governance: An empirical study of State Owned Enterprises in Indonesia. Accounting and Finance Review, 3(1), $26-32$.

Giovanis, E., \& Ozdamar, O. (2014). Determinants of Profitability: Evidence from US Firms. Facolta di Economia, Universita degli Studi di Verona.

Gupta, N. (2005). Partial Privatization and Firm Performance. The Journal of Finance, 60(2), 987-1015.

Hess, K., Gunasekarage, A., Hovey, M. (2010). State-dominant and non-state-dominant ownership concentration and firm performance: evidence from China. International Journal of Managerial Finance, 6(4), 264-289. 
Hossain, M., Prevost, A.K., \& Rao, R.P. (2001). Corporate governance in New Zealand: the effect of the 1993 Companies Act on the relation between board composition and firm performance. Pacific-Basin Finance Journal, 9(2), 119-145.

Itturalde, D., Maseda, D.A., \& Arosa, D.B. (2011). Insiders ownership and firms performance. Empirical evidence. International Research Journal of Finance and Economics, 67, 118-129.

Jackling, B., \& Johl, S. (2009). Board structure and firm performance: evidence from India's top companies. Corporate Governance: An International Review, 17(4), 492-509.

Jiang, B.B., Laurenceson, J., Tang, K.K. (2008). Share reform and the performance of China's listed companies. China Economic Review, 19(3), 489-501.

Kristiani, K. E., Sulindawati, N. L., \& Herawati, N. T. (2014). Pengaruh Mekanisme Corporate Governance dan Ukuran Perusahaan terhadap Manajemen Laba pada Perusahaan Manufaktur yang Terdaftar di BEI. EJournal Universitas Pendidikan Ganesha Jurusan Akuntansi Program S1 (Vol. 2 No.1)

Li, M.F., \& Wong, Y.Y. (2003). Diversification and economic performance: an empirical assessment of Chinese firms. Asia Pacific Journal of Management, 20(2), 243-265.

MacAvoy, P. W., McIsaac, G. S., Niskanen, W., \& De Alessi, L. (1989). The performance and management of United States federal government corporations. In Privatization and tate-owned enterprises (pp. 77-142). Springer, Dordrecht.

Ng, A., Yuce, A., \& Chen, E. (2009). Determinants of state equity ownership, and its effect on value/performance: China's privatized firms. Pacific-Basin Finance Journal, 17(4), 413-443.

Najid, N. A., \& Rahman, R. A. (2011). Government Ownership and Performance of Malaysian Government-Linked Companies. International Research Journal of Finance and Economics, 61, 42-56.

Nugroho, H. (2019). THE IMPACT OF GOVERNMENT SUPPORT. Asian Development Bank Institute. ADBI Working Paper Series, 983.

Organisation for Economic Co-operation and Development (OECD). 1998. Corporate Governance, State-Owned Enterprises, and Privatisation. Paris, France: OECD Publishing.

Panasian, C., Prevost, A.K., \& Bhabra, H.S. (2008). Voluntary listing requirements and corporate performance: the case of the Dey Report and Canadian firms. Financial Review, 43(1), 129-157.

Ochieng, M. D., \& Ahmed, A. H. (2014). The Effects of Privatization on the Financial Performance of Kenya Airways. International Journal of Business and Commerce, 3(5), 10-26.

Qi, D., Wu, W., \& Zhang, H. (2000). Shareholding structure and corporate performance of partially privatized firms: evidence from listed Chinese companies. Pacific-Basin Finance Journal 8(5), 587-610.

Razak, N.H.A., Ahmad, R. \& Aliahmed, H.J. (2008). Government ownership and performance: An analysis of listed companies in Malaysia. Corporate Ownership and Control, 6(2), 434-442.

Soejono, F., \& Heriyanto, H. (2018). Privatization and Firm Performance: a Study of Indonesia's State-owned Enterprises. Jurnal Dinamika Manajemen, 9(2), 149-158. https://doi.org/10.15294/jdm.v9i2.14970

Sun, Q., \& Tong, W. H. S. (2002). How Does Government Ownership Affect Firm Performance? Evidence from China's Privatization Experience. Journal of Business Finance and Accounting, 29(1-2), 1-27.

Tian, L., \& Estrin, S. (2008). Retained State Shareholding in Chinese PLCs: Does Government Ownership Always Reduce Corporate Value? Journal of Comparative Economics, 36, 74-89.

Ting, I. W. K., \& Lean, H. H. (2015). Does Government Ownership Matter? Comparative Study Between Glcs and Nglcs in Malaysia. The Singapore Economic Review, 60(02), 1550019. https://doi.org/10.1142/S0217590815500198

Tran, N. M., Nonneman, W., \& Jorissen, A. (2014). Government Ownership and Firm Performance: The Case of Vietnam. International Journal of Economics and Financial Issues, 4(3), 628-650.

Urga, G., Bennett, J., \& Estrin, S. (2007). Methods of Privatization and Economic Growth in Transition Economies. Economics of Transition, 15(4), 661-683.

Yu, M. (2013). State ownership and firm performance: Empirical evidence from Chinese listed companies. China Journal of Accounting Research, 6(2), 75-87. https://doi.org/10.1016/j.cjar.2013.03.003

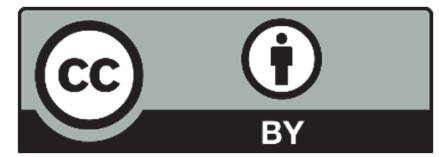

(C) 2021 by the authors; licensee Growing Science, Canada. This is an open access article distributed under the terms and conditions of the Creative Commons Attribution (CC-BY) license (http://creativecommons.org/licenses/by/4.0/). 